\title{
Virtual Public Space in Sketching Community
}

\section{Stefy Prasasti Anggraini', Ahmad Rosyid Wahyu Anggoro'}

\author{
${ }^{1}$ Architecture Department, Faculty of Civil Engineering And Planning, \\ Universitas Islam Indonesia, Yogyakarta
}

\begin{abstract}
Virtual Public Space in the sketch community has created by physical distancing during the covid-19 pandemic. The development of the spread of Covid-19, which is experiencing an increase, has changed the physical public space to turn into a virtual public space. Therefore the public space becomes part of the social space for a community, one of which is the sketch community. The sketch community in urban sketchers began to switch to using virtual public space during a pandemic. This study aims to find a pattern from virtual public space in a sketching community that architecture students follow. The method used is the descriptive qualitative method by taking four case studies from communities in Indonesia. According to students, the placemaking pattern of virtual public space from these four communities is necessary and valuable for independent sketching learning.
\end{abstract}

Keywords: community; placemaking; sketching; virtual public space

\section{Introduction}

BBC Indonesia informs that almost 39 million cases of Covid-19 in 18 countries around the world. (Indonesia, 2020) In several countries in Europe, as of October 14, Covid-19 cases increased in a few weeks written from the ECDC October 14 in the October 5, 2020 edition of BBC Indonesia, updated October 16, 2020 (Indonesia, 2020). Restaurants and public places in Germany and the Netherlands began to be limited again in the number of visitors and operational time. The increase also occurred in Indonesia; on October 3, 2020, there was an increase in the number of deaths of more than 12.000 to be the highest number in Southeast Asia. (Indonesia, 2020) With the increasing spread of Covid-19 during the newnormal period, public activities, for example, community gatherings, have not been able to meet face-to-face (United Nations, 2020).

The sketch community or urban sketcher is a community of sketch activists who often meet

Correspondence: Stefy Prasasti Anggraini

Architecture Department, Faculty of Civil Engineering

And Planning, Universitas Islam Indonesia, Yogyakarta

E-mail: stefy.prasasti.anggraini@uii.ac.id in public spaces to do live sketching/sketches directly or indirectly (Sketcher UsK, 2019). One of the forms of public space is the existence of a community. This community provides various forms of sketches seen from experience, observations, and multiple techniques in drawing. It's valuable as material for the breadth of knowledge (Briggs, 2018).

The process of doing this sketch is part of the tools for recording events, experiences in space and time (Briggs, 2018). It's useful for students to learn independently by following the sketch community to support the learning process about sketching. The sketching community provides skills and knowledge for the student to understand and sharing about sketching. Since 2010, Arengi or a sketching community formed from several students and lectures in the Department of Architecture, UII has become a community forum to share spatial experiences in learning sketch drawing (Arengi, 2020). In 2017, This community started its activities again by inviting several students and lecturers to share their passion for sketching. 
Virtual Public Space in Sketching Community Stefy Prasasti Anggraini, Ahmad Rosyid Wahyu Anggoro
It is the same as what was done by the Urban Sketcher community Usk (Urban Sketcher) in 2007 in settle-based journalist and illustrator Gabriel Campanario. They do an online forum for sketchers around the world to love sketching. Usk's slogan is to see the world, One Drawing at a time (Sketcher UsK, 2019). Urban sketcher starting to draw during a pandemic when saw sketchbooks purchased for a long time but had not used. The sketchbook was finally usable during the quarantine period, and the sketcher started sketching again. The pandemic period due to Covid-19 provides a new space for Urban sketchers to continue to sketch even if it is only done at home and continue to communicate online in virtual public space (Sketcher UsK, 2019).

This research aims to find the benefits of virtual sketching in the placemaking of the virtual public spaces in the sketching community. The placemaking of virtual public space in the sketching community from four cases of sketching community activities can support architecture's students to improve skills and knowledge about sketching in the pandemic covid-19 period.

\section{Literature Review}

\section{Virtual Public Space in Digital Era}

Physical changes to Public Space after the COVID-19 pandemic caused restrictions on joint activities, one of which was activities in public spaces (Jasiński, 2020). PPS on its website with the title Portals to Place: Supporting Public Space with Digital Space explains the role of Public Space physically and digitally/virtually (PPs,2000). This article explains that Place digital technology and local communities are connected online / online with the environment (Aguila et al., 2019).

However, this is how placemaking has the opportunity to unite the community and digital space (Haas, 2020). Average condition, the idea of virtual space had already begun to be discussed in the world of learning. Virtual Design Studio is one example.

It's part of the learning process about Architecture and Urban Design (Sun et al., 2014).
Using the diagram "What Makes a Successful Public Space, there are four elements of placemaking in the research in question, namely Public Space related to Digital Placemaking. Digital Placemaking integrates social media with placemaking practices, one of which is community-centred (Latorre, 2011).

The four elements of placemaking according to PPS are as follows: (1) Access \& Linkages (2) Comfort \& Image (3) Uses \& Activities (4) Sociability. Access and linkage are related to the achievement of access to space. The space here has entered the physical space in public Space and digital/virtual Space (Virtual Public Space). The convenience brought to show a good picture of any virtual comfort formulated. Users and activities that invite sketchers to gather online. The fourth element is sociability which causes people to accumulate at one time (PPS, 2009).

Figure 1. The Place Diagram "What Makes A Great Place" Source: PPS, 2010

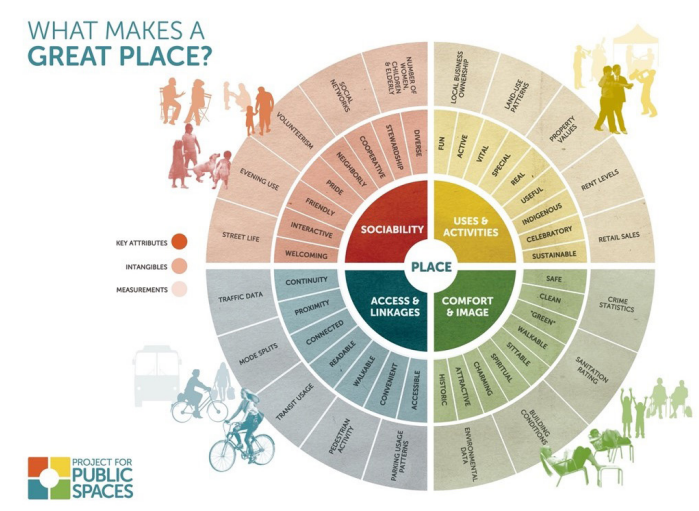

In placemaking, the sense of community forms with social aspects and interactions in an environment and public space (Cilliers, 2019). Public space in this study provides an opportunity for virtual space in virtual public space to be a reinforcement of physical public space during this pandemic.

Virtual Public Space forms the concept of digital placemaking. Where public space begins to connect a new environment and its connection with technology. (Hespanhol, 2018). In placemaking, it is not just a relationship between people and places. However, also on how to make connections between people and places (Ghavampour \& Vale, 2019). 


\section{Virtual Public Space as third place}

A paper explains the third place present in the public space as a phenomenon of changing the need for public space to improve the quality of life of human beings (Ellisa, 2019). According to Ellisa, 2019 the need for different spaces in the digital era appears in (1) the Third Room as a community centre, (2) the Third Room in the Digital Age. The Third Room as a community centre arises because of the social phenomenon of togetherness at work, gathering for hobbies etc. The Third Space in the Digital Age, which was previously digital, did not have a strong connection to the emergence of space; now digital makes this third space strong because it is a factor in the formation of this third space. From some of the explanations above, explaining this digital/virtual factor is essential to be discussed and considered as part of changing space-forming factors.

Third place in social aspect relates to meaning place as gathering and has outcomes a community loyalty (Rosenbaum, 2006). It has a similar meaning of third place in Virtual Public Space in the Sketching community. The concept of virtual third place uses all active communities in the community and moves their community to contribute to what a virtual third place means in a virtual community (Markiewicz, 2019).

In this case, the third-place during a pandemic is nothing new. It has become an essential aspect of digital placemaking in the community, especially in this research, the sketch community.

\section{Case Study in Sketching Community}

The first Case Study from Indonesia's Sketcher This sketch community started at Urban Sketcher (USk), starting in 2007 in Settle-based journalist and illustrator Gabriel Campanario. (Usk, 2019) UsK provides an online forum for sketchers worldwide who love sketches of cities they live in and visit or sketches of houses, cafes, parks. Usk's slogan is See the World, One Drawing at a Time. Then this community appeared in various countries, one of which was Indonesia's sketcher. This community organizes their time every month, quarterly or once a year with multiple activities. Observation of the literature is seen from the process of activities in the new normal (Sketcher UsK, 2019).

\section{Second Case Study from Arengi Sketch community}

The Arengi sketch community has carried out Virtual Sketching activities during the pandemic, which was carried out by uploading sketches to the Instagram portal @Arengi.reborn (Arengi, 2020).

\section{The third Case Study Took Part in The Virtual Sketch Competition held by ArsiSKETur}

The ArsiSKETur Sketch Community from Semarang held a virtual sketch competition. By participating in this competition as a tool to see real cases and record them and explore to see the character of Virtual Public Space (Arsisketur, 2020).

The fourth Case Study Participated in Activities in the GBK (Gambar Bareng Kita/ Sketch with us) Community

A Sketch Community called GBK appeared on Instagram and created a community for drawing together. The activity process is carried by uploading works with various themes every week to the Instagram page and posting in the community WAG (Social Media Group) (GBK, 2020).

Figure 2. Sketch Community Activities

Source: Screenshot of Instagram's community

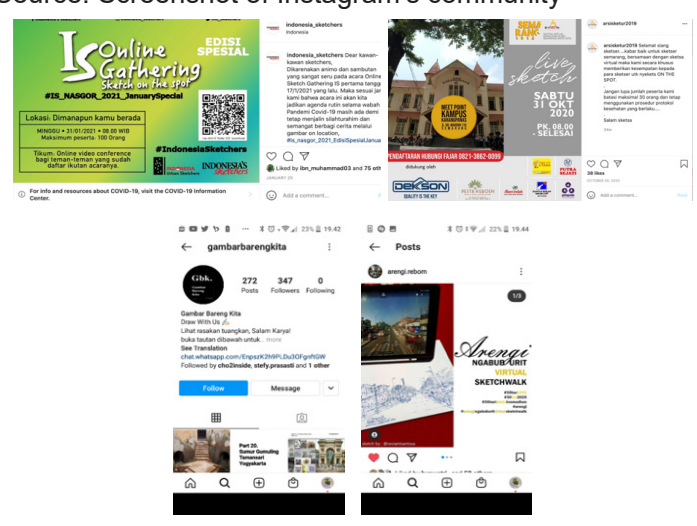

\section{Methodology}

This study uses descriptive qualitative research methods with direct observation of participating in a virtual sketch competition. Then, collect literature data explaining Virtual Public Space and the sketch community from various sources, libraries, web pages, social media (because it involves virtual space), journals, and books (Groat, 2013). 
Qualitative research methods are more straightforward and based on the perception of a person or group. In this study, researchers observed activities in Virtual Public Space that occurred in 4 sketch communities, namely (1) the Usk Urban Sketcher Community, which is a global sketch community, (2) Arengi Local Community, which is a community formed from several students and lecturers of Architecture. UII, and then (3) other Local Communities -Architects who held virtual sketch competitions as participants to directly observe the observed Virtual Public Space. (4) The GBK Community (Gambar Bareng Kita/ Sketch with Us) holds group drawing activities regularly and on different topics every two weeks.

Table 1. Table of sketching activity in research

\begin{tabular}{|c|c|c|c|c|}
\hline No & $\begin{array}{l}\text { Communities' } \\
\text { name }\end{array}$ & $\begin{array}{l}\text { Activities' } \\
\text { name }\end{array}$ & Time & Duration \\
\hline 1 & $\begin{array}{l}\text { Indonesia's } \\
\text { Sketcher }\end{array}$ & $\begin{array}{l}\text { IS Online } \\
\text { Gathering } \\
\text { Sketch on } \\
\text { the spot }\end{array}$ & $\begin{array}{l}31 / 01 / 2021 \\
08.00\end{array}$ & $\begin{array}{l}1 \text { day, } \\
\text { periodically }\end{array}$ \\
\hline 2 & Arsisketur & $\begin{array}{l}\text { Sketsa } \\
\text { Virtual } \\
\text { Heritage } \\
\text { Architecture } \\
\text { in } \\
\text { Semarang } \\
\text { Kota Atas }\end{array}$ & $\begin{array}{l}31 / 10- \\
1 / 11 / 2020 \\
08.00\end{array}$ & $\begin{array}{l}2 \text { Days, } \\
\text { periodically }\end{array}$ \\
\hline 3 & Arenga & $\begin{array}{l}\text { Arengi } \\
\text { Virtual } \\
\text { Sketchwalk }\end{array}$ & $\begin{array}{l}\text { April } 24 \\
2020 \text { dan } \\
\text { April } 31 \\
2021 \\
\text { Moment of } \\
\text { Ramadhan } \\
\text { mount }\end{array}$ & Periodically \\
\hline 4 & GBK & $\begin{array}{l}\text { Gambar } \\
\text { Bareng Kita } \\
\text { with spesific } \\
\text { topic of } \\
\text { sketch } \\
\text { object }\end{array}$ & $\begin{array}{l}\text { Once a } \\
\text { week }\end{array}$ & $\begin{array}{l}\text { I theme } \\
\text { in } 1 \text { week } \\
\text { periodically }\end{array}$ \\
\hline
\end{tabular}

Source: Author

This research consists of 3 stages, namely (1) Primary and Secondary Data Collection, (2) Data Grouping according to the parameters used, (3) Conducting analysis. Parameters are arranged based on placemaking factors, especially digital ones, which will later become a benchmark for analysis based on the object of observation observed from primary and secondary data.

Of the four categories used in observing activities in the four cases of the existing sketch community, analysis results will be obtained about the characteristics of the formation and provide alternative directions for the needs of Virtual Public Space for students. The process of observation participating in activities organized by the four sketch communities, which had a variety of (1) access, (2) comfort \& visuals, (3) needs \& activities, and (4) Sociability during the pandemic.

The analysis process explains every aspect that becomes an indicator in each activity followed. The result will appear that the characteristics of the Virtual Public Space pattern are diverse and can formulate the framework of the placemaking pattern and independent study space for students to learn about sketches in architecture in particular.

\section{Result and Discussion}

The researcher took data from two processes, the first using secondary data with existing literature studies from existing websites and social media pages. The first process was to follow one of the activities held by the community during the research or previously conducted.

Table 2. Table of sketch object, techniques and media

\begin{tabular}{lllll}
\hline No & $\begin{array}{l}\text { Name of } \\
\text { community }\end{array}$ & $\begin{array}{l}\text { Sketch's } \\
\text { Object }\end{array}$ & $\begin{array}{l}\text { Sketching } \\
\text { techniques }\end{array}$ & $\begin{array}{l}\text { Sketch } \\
\text { Media }\end{array}$ \\
\hline 1 & $\begin{array}{l}\text { Indonesia's } \\
\text { Sketcher }\end{array}$ & $\begin{array}{l}\text { Daily } \\
\text { surrounding } \\
\text { object (home, } \\
\text { or even in } \\
\text { urban area) }\end{array}$ & Live Sketching & paper \\
& Arsisketur & $\begin{array}{l}\text { Heritage's } \\
\text { Architecture }\end{array}$ & $\begin{array}{l}\text { Live sketching } \\
\text { and sketch } \\
\text { from photo }\end{array}$ & $\begin{array}{l}\text { Paper and } \\
\text { digital }\end{array}$ \\
3 & Arenga & $\begin{array}{l}\text { Architecture, } \\
\text { heritage } \\
\text { architecture }\end{array}$ & \\
& & $\begin{array}{l}\text { Architecture, } \\
\text { heritage } \\
\text { architecture }\end{array}$ & & \\
\hline
\end{tabular}

Source: Author

The sketch community studied has a different scope of space seen from the distribution of the community. The following describes the introduction of the four communities in general with the research indicators used to explain the character of virtual public space. The observation came from 4 communities during the Covid-19 pandemic. The following details the time of the activities carried out as part of the research process carried out. 
The results show that there are variations of placemaking virtual public space in the four communities. The following describes the diversity of aspects of accessibility, comfort and image, user and activities, and sociability.

In this research, the author finds how the sketching community provides some contributions to architecture, such as finding the placemaking of somewhere with unique architecture and environment and learning about heritage architecture. Some sketches (Figures 8 and 9) explain how the sketching community provides a place to give users various experiences. Placemaking Theory gives an alternative to finding a virtual place as a third place to support sketching in the Covid-19 pandemic.

Figure 3. Accessibility in virtual public space of sketching community

Source: Author

Access \& Linkage in sketching community

\begin{tabular}{|c|c|c|}
\hline $\begin{array}{c}\text { Connections between } \\
\text { institutions/organizatio } \\
\text { ns and communities }\end{array}$ & $\begin{array}{c}\text { Equal } \\
\text { access for } \\
\text { all sectors }\end{array}$ & $\begin{array}{l}\text { Community } \\
\text { building } \\
\text { resources } \\
\text { available }\end{array}$ \\
\hline $\begin{array}{l}\text { Information via } \\
\text { Instagram, } \\
\text { facebook, } \\
\text { Whatsappa Group } \\
\text { / social media }\end{array}$ & $\begin{array}{l}\text { Equal access } \\
\text { in Zoom } \\
\text { room, WAG } \\
\text { and activity } \\
\text { access }\end{array}$ & $\begin{array}{l}\text { There are supporting } \\
\text { activities and nursing } \\
\text { homes/core teams, } \\
\text { workshops, joint } \\
\text { sketches, exhibitions }\end{array}$ \\
\hline
\end{tabular}

Figure 4 Comfort and Image in virtual public space of sketching community

Source: Author

Comfortability in sketching community

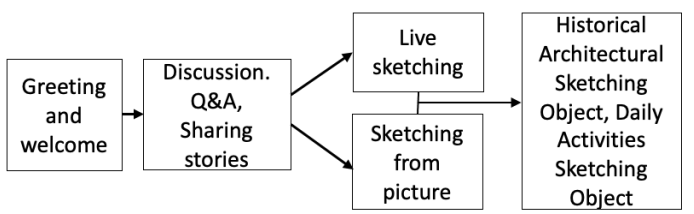

Figure 5. Activities and User aspects in virtual public space of sketching community

Source: Author

Activities and user in sketching community

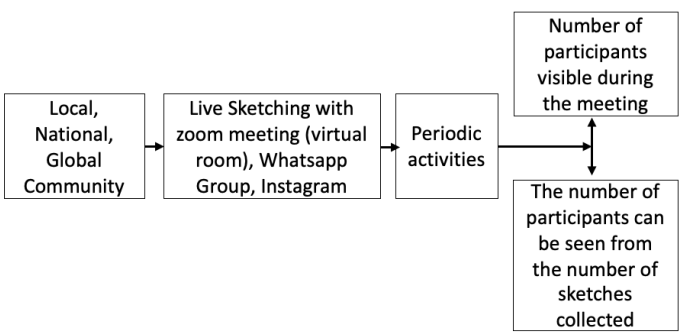

Figure 6. Sociability

Source: Author

\section{Sociability in sketching community}

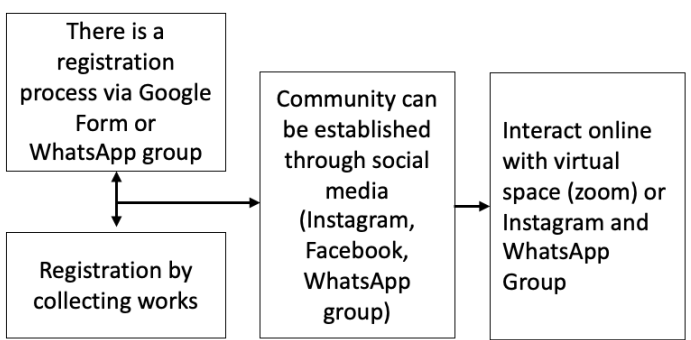

From the aspect of accessibility, there are various social media users, such as Instagram, Facebook and Whatsapp groups. In addition to being accessible and affordable, access is also available for the development of activities other than drawing together, namely, virtual workshops and exhibitions.

Figure 7. Indonesia's Sketcher Activities in virtual public space

Source: Author

INDONESIA'S SKETCHER

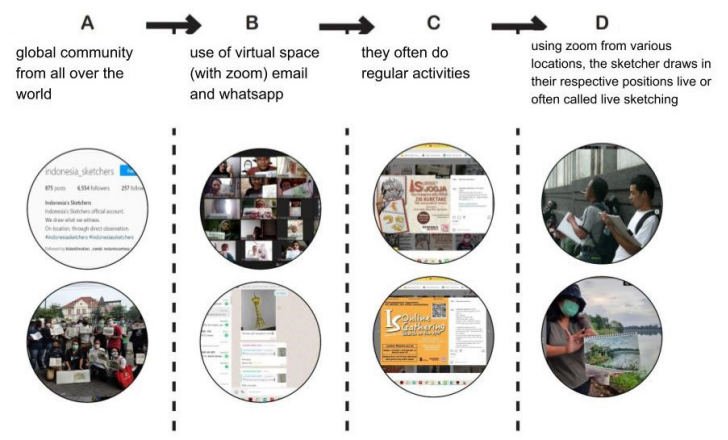

Easy accessibility can support by visual comfort. Between participants and committee have greetings. There is an interaction between participants, committee and resource persons. The object can use various techniques with various things, from urban sketching, heritage architecture. How to draw also varies; some are live sketching around the residential environment because they are physically distancing. Some draw with photos chosen by the committee and participants.

This community comes from local, national, and international levels; the zoom platform (virtual room) deals with virtual face-to-face. Community activities also periodically have their character, from certain moments to periodic ones such as once a week to once a month. 
Virtual Public Space in Sketching Community Stefy Prasasti Anggraini, Ahmad Rosyid Wahyu Anggoro
Sociability aspects come from the registration process and collection of works, and after the activity, participants can participate in following community activities and maintain communication.

The four Sketching communities provide the various experience of places. In figure 8, Anggoro's sketches provide multiple objects with different places by virtual public space in sketching community events. In Anggraini's sketches also offer various things to sketch and the character of place with various sketch tools (Figure 9).

From direct observation, this research collects questionnaires to architecture students from various universities to find out the effectiveness and benefits of virtual public space. The questionnaire data noted that 33 respondents answered and expressed their opinion about virtual public space in the sketch community. Easy access to join the community recorded $84,9 \%$ indicated that it was easy to join the community, the rest were relatively easy. Social media turned out to be helpful and easy to access information about the sketch community, recording $81.8 \%$. The registration process in the community is essential, recorded at $75.8 \%$. Greeting each other, sharing experiences and discussions are considered necessary; $63.6 \%$ answered strongly agree. Activities held regularly are also important, recorded at $66.7 \%$.

The results showed a value of more than $50 \%$. It shows that virtual public spaces assisted by digital platforms can help the sketch community during a pandemic, recorded at $63.6 \%$ and can be a new alternative for the community, recorded at $57.6 \%$.

Although respondents agree that virtual public space is valuable, $72.7 \%$ hope to have physical public space again after the pandemic, and $60.6 \%$ answered that virtual public space can still support the sketch community after the pandemic subsides.
Figure 8. Sketches result in four sketching community events.

(a)Arengi event, Pesanggrahan Taman Siswa Yogyakarta, 2020, (b)GBK event, Banco Bilbou Viscaya Argentaria Bank, Spain, 2020, (c)Indonesia Sketcher event, Plants neat at home, Solo, 2021, (d)Arsisketur event, Heritage Building, Church in Semarang, 2020

Source: Anggoro, 2020
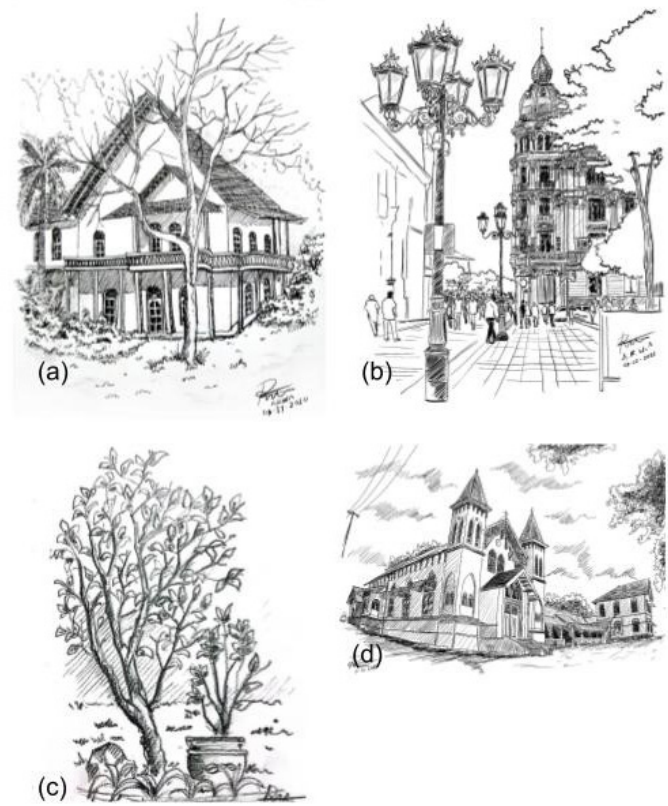

Figure 9. Sketches result in four sketching community events.

(a)Arengi events: Gateway of Agung Masjid, Surakarta, 2020, (b)GBK event: Banco Bilbou ViscayaArgentaria Bank, Spain, 2020, (c)Arsisketur event: Goodfellas, Semarang, 2020, (d)House in Adisucipto Street, Yogyakarta, 2021 Source: Anggraini, 2020

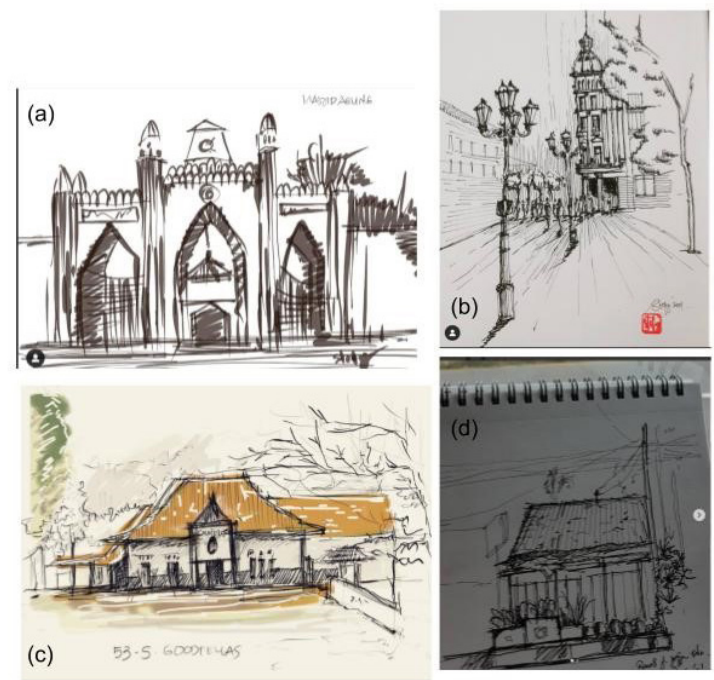


Figure 10. Characteristic of Virtual Public Space in Sketching Community

Source: Author

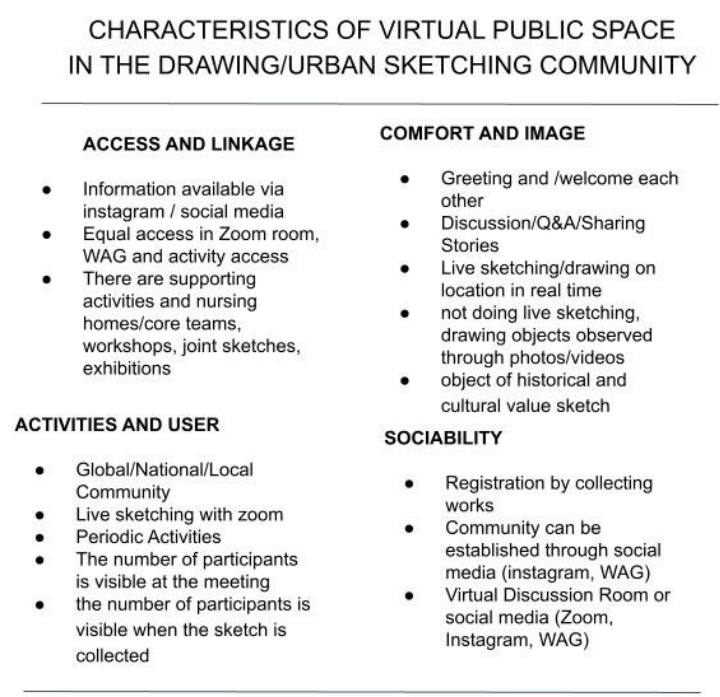

\section{Conclusion}

The conclusion from this research explains that Virtual Public Space is closely related to the community as a central part of public Space (Community-center based), which provides virtual public space opportunities as an alternative in adapting during a pandemic to stay social and interact in a shared space. Social media and virtual room platforms as part of the placemaking factors in virtual public spaces.

\section{Acknowledge}

Finally, the authors would like to thank the Department of Architecture, Faculty of Civil Engineering, Universitas Islam Indonesia, to support this research in the research grant scheme and all colleagues.

\section{References}

Aguila, M. Del, Ghavampour, E., \& Vale, B. (2019). Theory of place in public space. Urban Planning, 4(2 Public Space in the New Urban Agenda Research into Implementation), 249-259. https://doi. org/10.17645/up.v4i2.1978

Arengi. (2020). Sketching Community Instagram. https://www.instagram.com/ arengi.reborn/

Arsisketur. (2020). Sketching Community's Instagram. https://www.instagram.com/ arsisketur2019/
Briggs, R. (2018). Using drawing as a tool to explore public space. The Journal of Public Space, 3(Vol. 3 n. 2 | 2018 | FULL ISSUE), 115-148. https://doi.org/10.32891/jps. v3i2.1112

Carmona, M. ; C. de M. and L. H. (2008). Public Space the management dimension. In Paper Knowledge. Toward a Media History of Documents. Routledge.

Carmona, M., Heath, T., Oc, T., \& Tiesdell, S. (2003a). Public spaces. Urban spaces. In The Dimension of Urban Design (Vol. 1).

Carmona, M., Heath, T., Oc, T., \& Tiesdell, S. (2003b). Urban spaces-public places: The dimensions of urban design.

Cilliers, E. J. (2019). Planning for third places through evidence-based urban development. In Rethinking Third Places (Issue March, pp. 73-94). https://doi. org/10.4337/9781786433916.00013

Francis D.K., C. (2013). Grafik Arsitektur Edisi Kelima. Erlangga.

GBK. (2020). Sketching Community's Instagram. https://www.instagram.com/ gambarbarengkita/

Ghavampour, E., \& Vale, B. (2019). Revisiting the "model of place": A comparative study of placemaking and sustainability. Urban Planning, 4(2 Public Space in the New Urban Agenda: Research into Implementation), 196-206. https://doi. org/10.17645/up.v4i2.2015

Groat, L. and D. W. (2013). Architectural Research Methods Second Edition.

Haas, T. (2020). Enabling Intragenerational third places as New Incubators of Sociability and Placemaking in Times of Transition. Scholarly Journal of Psychology and Behavioral Sciences, 4(2), 418-424. https://doi.org/10.32474/ sjpbs.2020.04.000183

Hespanhol, L. (2018). Making Meaningful Spaces : Strategies for Designing Enduring Digital. International Conference on Design, Innovation and Creativity (SAAN), July, 108-117.

Honey-Rosés, J., Anguelovski, I., Chireh, V. K., Daher, C., Konijnendijk van den Bosch, C., Litt, J. S., Mawani, V., McCall, M. K., Orellana, A., Oscilowicz, E., Sánchez, U., Senbel, M., Tan, X., Villagomez, E., Zapata, O., \& Nieuwenhuijsen, M. J. (2020). The impact of COVID-19 on public space: an early review of the emerging questions design, perceptions and inequities. Cities \& Health, 1-17. https://doi.org/10.1080/2374 
8834.2020.1780074

Imam, M. M., Bakr, A. F., \& Anany, Y. M. (2016). Use of freehand sketching: Documenting heritage buildings, Gamal Abdel Nasser Street (1830-1930), Alexandria, Egypt. Alexandria Engineering Journal, 55(3), 2749-2764. https://doi.org/10.1016/j. aej.2016.04.034

Indonesia, B. (2020). Covid-19 'terus menyebar', hampir 39 juta kasus terkonfirmasi di 189 negara - bagaimana upaya negara-negara yang masih alami kenaikan kasus? Https://Www.Bbc.Com/ Indonesia/Dunia-54407978. https://www. bbc.com/indonesia/dunia-54407978

Jasiński, A. (2020). Public space or safe space - remarks during the COVID-19 pandemic. Technical Transactions, 1-10. https://doi. org/10.37705/techtrans/e2020020

Kemendikbud. (2021). Apa Kata Nadiem Tentang Reformasi Pendidikan. 31 May. https://itjen.kemdikbud.go.id/public/post/ detail/apa-kata-nadiem-tentang-reformasipendidikan.

Latorre, D. (2011). Digital Placemaking Authentic Civic Engagement. PPS. https:// www.pps.org/article/digital-placemakingauthentic-civic-engagement

Markiewicz, E. (2019). Third Places in the Era of Virtual Communities. Studia Periegetica, 4(28).https://doi.org/10.26349/ st.per.0028.01

Nash, A., Geck, K., \& Miller, A. (2021). Virtual Interiorities. Interiority, 4(2), 207-222. https://doi.org/10.7454/in.v4i2.153

Peng, C. (2021). Self-regulated Learning Behavior of Collega Students of Art and Their Academic Achievement,". Nternational Conference on Medical Physics and Biomedical Engineering.

PPS. (2009). Portals To Place: Supporting Public Space with Digital Space. PPS. https://www.pps.org/article/digitalplacemaking

RFP Hadi and Ellisa, E. (2019). Rethinking third place in the digital era. International Conference on Informatics, Technology and ENgineering, November.

Rosenbaum, M. S. (2006). Exploring the social supportive role of third places in consumers' lives. Journal of Service Research, 9(1), 59-72. https://doi. org/10.1177/1094670506289530

Saunders, C., Rutkowski, A. F., Van Genuchten, M., Vogel, D., \& Orrego, J. M. (2011) Virtual space and place: Theory and test.
MIS Quarterly: Management Information Systems, 35(4), 1079-1098. https://doi. org/10.2307/41409974

Sketcher UsK, U. (2019). Our Manifesto. 1 January. http://www.urbansketchers.org/p/ our-manifesto.html

Sun, L., Fukuda, T., \& Resch, B. (2014). A synchronous distributed cloudbased virtual reality meeting system for architectural and urban design. Frontiers of Architectural Research, 3(4), 348-357. https://doi.org/10.1016/j.foar.2014.05.001

United Nations. (2020). The Impact of COVID-19 on South-East Asia. In Policy Briefs.

Wyckoff, M.A. (2014). Definition of Placemaking: Four Different Types. Planning \& Zoning News. www.miplace.org. 